\title{
Little evidence of transdifferentiation of bone marrow-derived cells into pancreatic beta cells
}

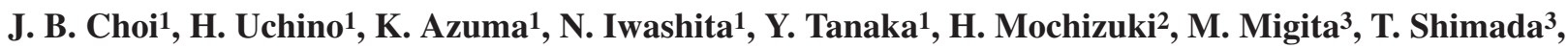 \\ R. Kawamori' ${ }^{1}$ H. Watada 1 \\ ${ }^{1}$ Department of Medicine, Metabolism and Endocrinology, Juntendo University School of Medicine, Bunkyo-ku, \\ Tokyo, Japan \\ 2 Department of Neurology, Juntendo University School of Medicine, Tokyo, Japan \\ ${ }^{3}$ Department of Biochemistry and Molecular Biology, Division of Gene Therapy, \\ Research Center for Advanced Medical Technology, Nippon Medical School, Tokyo, Japan
}

\section{Abstract}

Aims/hypothesis. Bone marrow cells contain at least two distinct types of stem cells which are haematopoietic stem cells and mesenchymal stem cells. Both cells have the ability to differentiate into a variety of cell types derived from all three germ layers. Thus, bone marrow stem cells could possibly be used to generate new pancreatic beta cells for the treatment of diabetes. In this study, we investigated the feasibility of bone marrow-derived cells to differentiate into beta cells in pancreas.

Methods. Using green fluorescent protein transgenic mice as donors, the distribution of haematogenous cells in the pancreas was studied after bone marrow transplantation.

Results. In the pancreas of green fluorescent protein chimeric mice, green fluorescent protein-positive cells were found in the islets, but none of these cells expressed insulin. Previous data has suggested that tissue injury can recruit haematopoietic stem cells or their progeny to a non-haematopietic cell fate. Therefore, low-dose streptozotocin (30 or $50 \mathrm{mg} / \mathrm{kg}$ on five consecutive days) was injected into the mice 5 weeks after bone marrow transplantation, but no green fluorescent protein-positive cells expressing insulin were seen in the islets or around the ducts of the pancreas. Conclusions/interpretation. Our data suggests that bone marrow-derived cells are a distinct cell population from islet cells and that transdifferentiation from bone marrow-derived cells to pancreatic beta cells is rarely observed. [Diabetologia (2003) 46:1366-1374]

Keywords Regeneration, regeneration therapy, insulin, islet, stem cell, haematopoietic stem cell, mescenchymal stem cell, bone marrow.
The pancreas is composed of exocrine and endocrine compartments. The endocrine compartment consists of the islets of Langerhans, which contain clusters of

Received: 3 April 2003 / Revised: 10 June 2003

Published online: 26 July 2003

C) Springer-Verlag 2003

Corresponding author: H. Watada MD, Department of Medicine, Metabolism and Endocrinology, Juntendo University School of Medicine, 2-1-1 Hongo, Bunkyo-ku, Tokyo 1138421, Japan

E-mail: hwatada@med.juntendo.ac.jp

Abbreviations: STZ, streptozotocin; EGFP, enhanced green fluorescent protein; GP, guinea-pig; vWF, von Willebrand Factor; BrdU, bromodeoxyuridine; GFP, green fluorescent protein; IPGTT, Intraperitoneal glucose tolerance test. four cell types: glucagon-producing alpha cells, somatostatin-producing delta cells, pancreatic polypeptide-producing PP cells, and insulin-producing beta cells. An inadequate mass of functional pancreatic beta cells is found in both Type 1 and Type 2 diabetes. Thus, beta-cell replacement therapy is thought to be a possible curative treatment for diabetes. In order to make beta-cell replacement therapy more widely available, since islet transplantation is currently the only method of beta-cell replacement therapy, new sources of beta cells need to be explored.

Each tissue or organ is believed to contain a small sub-population of cells that is capable of self-renewal and has the ability to give rise to each mature cell type [1]. Thus, one of the most promising sources of beta cells might be pancreatic stem cells. While several 
studies have shown the existence of pancreatic stem cells $[2,3,4,5]$, these cells have not yet been isolated from the pancreas in a pure form.

Cells derived from bone marrow have been used to replace haematopoietic stem cells in the treatment of various haematological malignancies. These cells include both haematopoietic stem cells and mesenchymal stem cells, which can differentiate into various types of cells derived from the mesenchyme [6]. Recent studies using methods for tracking cell lineage have allowed us to identify the differentiation of bone marrow stem cells and mescenchymal stem cells into specific cells residing in various tissues $[7,8,9]$. Isolated haematopoietic stem cells might contribute to the epithelium of multiple organs of endodermal and ectodermal origin $[10,11,12]$. In contrast, mesenchymal stem cells can have a wider range of fates including transformation into endothelial, myogenic, hepatic, and neural cells [13].

Several lines of evidence suggest that tissue injury enhances the recruitment of haematopoietic stem cells, mescenchymal stem cells, or their progeny towards a non-haematopoietic fate $[11,14,15,16]$. This might be because migration of bone marrow stem cells throughout the body essentially act as a back-up system to augment each organ's intrinsic regenerative capacity.

Streptozotocin (STZ) induces diabetes by specific destruction of pancreatic beta cells. Multiple subdiabetogenic doses of STZ provoke different changes in the pancreas from a single injection of a diabetogenic dose of STZ $[17,18,19]$ and enable us to observe the re-organization of pancreatic beta cells [20]. Thus, multiple low doses of STZ are considered to create a good model for observing regeneration after beta-cellspecific injury. However, as far as we know, there has been no detailed investigation of whether bone marrow stem cells can differentiate into pancreatic beta cells after tissue injury.

Achieving the reconstitution of pancreatic beta cells by use of bone marrow-derived cells suggests that bone marrow cells are a feasible source for betacell replacement therapy. To elucidate the potential of bone marrow-derived cells for use as beta-cell replacement therapy, we established chimeric mice with the bone marrow of transgenic mice constitutively expressing enhanced green fluorescent protein (EGFP) $[16,21,22,23]$. As we showed previously, the bone marrow of these chimeric mice is almost completely reconstituted with EGFP-positive cells 5 weeks after transplantation [22]. These chimeric mice allow us to track the progeny of transplanted bone marrow cells, by using green fluorescence as a marker.

\section{Materials and methods}

Reagents. Among the primary antibodies, rabbit anti-Pdx 1 antibody was generated as described previously [24], while mouse anti-nestin antibody was kindly provided by Dr. S.

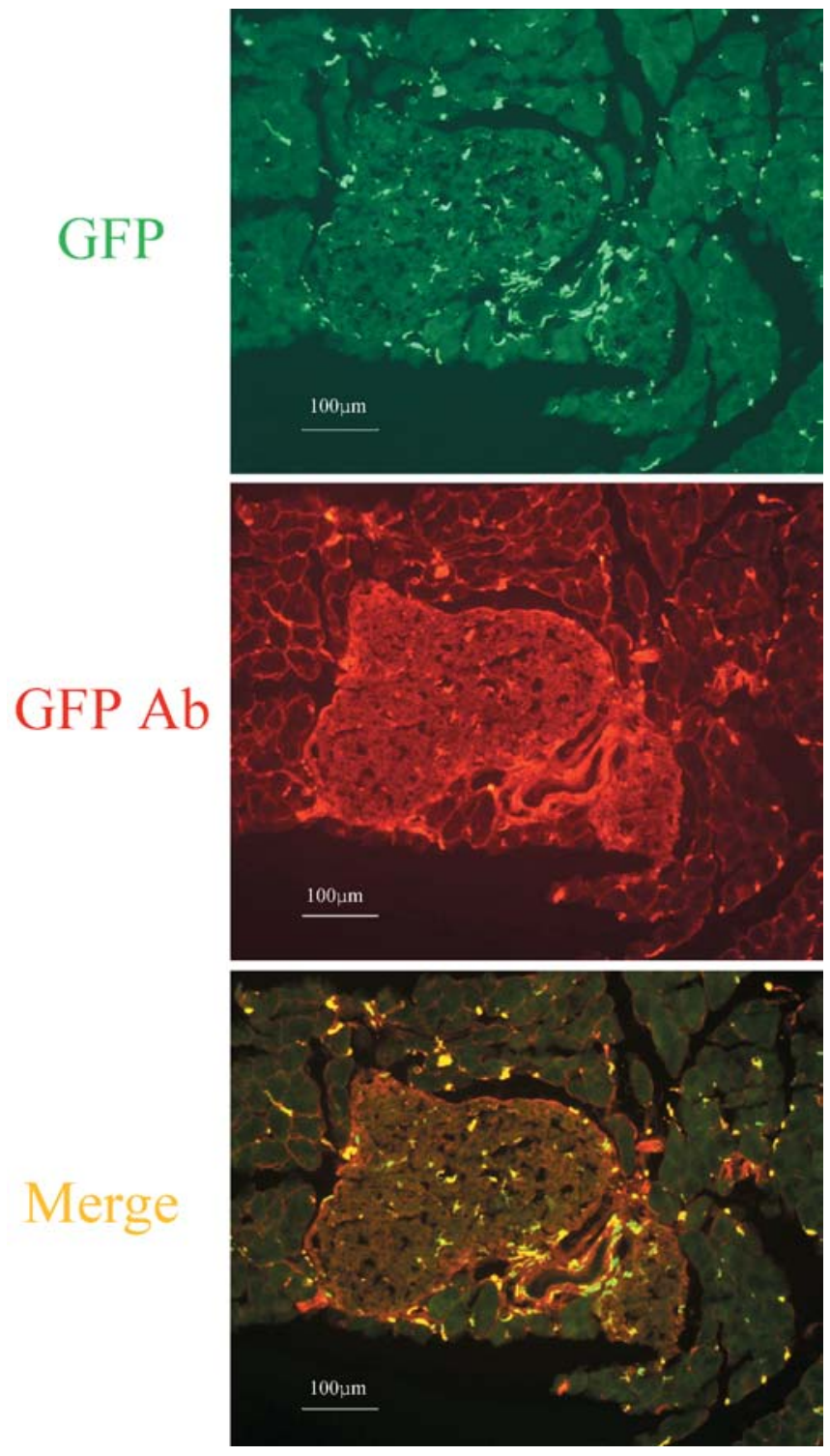

Fig. 1. Distribution of GFP-positive cells in the pancreas. Frozen pancreatic sections from GFP chimeric mice. Sections from mice at 5 weeks after bone marrow transplantation were observed by fluorescence microscopy without any staining (upper panel) and after staining with anti-GFP antibody (middle panel). A merged image is shown in the lower panel

Hockfield (Yale University, New Haven, Conn., USA). All other antibodies used for this study were purchased from commercial sources: guinea-pig (GP) anti-human insulin antibody (Linco, St. Charles, Mo., USA), rabbit anti-glucagon antibody (Dako, Carpinteria, Calif., USA), anti-CD45 antibody (Pharmingen, Franklin Lakes, N.J., USA), rabbit anti-Factor VIII related antigen/von Willebrand Factor (vWF) (Dako, Glostrup, Denmark), rat anti-bromodeoxyuridine (BrdU)(OBT, Oxford, UK), mouse anti-green fluorescent protein (GFP) antibody (Sigma-Aldrich, St. Louis, Mo., USA), and mouse anti-E-cadherin antibody (BD Bioscience, Flanklin Lakes, N.J., USA). All of the secondary antibodies came from commercial sources: biotinylated goat anti-rabbit IgG (Vector, Burlingame, Calif., USA), biotinylated goat anti-mouse IgG (Biomeda, Foster, Calif., USA), biotinylated goat anti-rat IgG (Cedarlane, Ontario, 


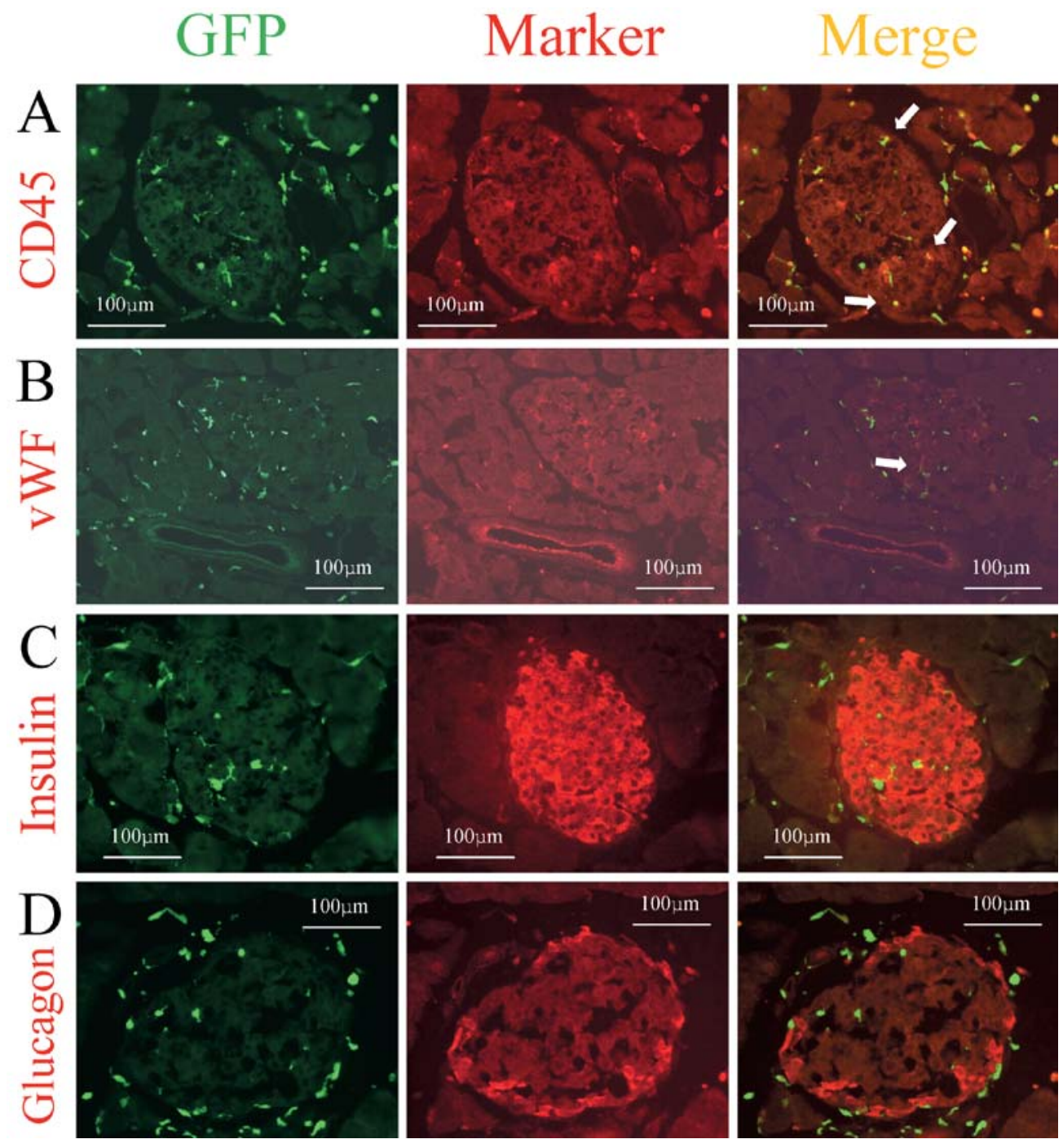

Fig. 2A-H. Expression of several markers by GFP-positive cells in the pancreas. Immunohistochemical analysis was carried out on cryostat sections $(4 \mu \mathrm{m})$ from GFP chimeric mice. Left, middle, right panels show GFP as green, each marker as red, and the merged images, respectively. Sections were immunostained with anti-CD45 antibody (A), anti-vWF antibody (B), anti-insulin antibody (C), anti-glucagon antibody (D), anti-E-cadherin antibody $(\mathbf{E})$, anti-nestin antibody $(\mathbf{F})$, and anti$\mathrm{Pdx} 1$ antibody $(\mathbf{G}, \mathbf{H})$. White arrows indicate cells expressing both GFP and the respective marker

Canada), goat anti-GP IgG conjugated Texas-red (Cortex, Sanleandro, Calif., USA), and goat anti-mouse IgG conjugated with Alexa 568 (Molecular Probes, Eugene, Ore., USA)

Animals and creation of GFP chimeric mice. Male C57BL/6 mice (18-20 g) were purchased from Japan SLC at 8 weeks of age and maintained in the animal facility of Juntendo University School of Medicine. The animals were allowed free access to a standard laboratory diet and water. GFP transgenic mice, in which EGFP expression was under the control of the cytomegalovirus enhancer and the chicken $\beta$-actin promoter, were generously provided by Dr. M. Okabe (Osaka University, Osaka, Japan) [25]. Using these transgenic mice, we generated GFP chimeric mice $[16,22]$, in brief, bone marrow transplantation was carried out with 8-week-old C57BL/6,GFP mice as the donors and 8-week-old C57BL/6 mice as the recipients. Donor bone marrow cells were obtained from the femurs and tibias of GFP mice after the injection of 5-fluorouracil $(150 \mathrm{mg} / \mathrm{kg})$ at $48 \mathrm{~h}$ before transplantation, and were injected into the tail veins of irradiated $(5 \mathrm{~Gy} \times 2)$ non-transgenic recipient mice. All the experiments were conducted in accordance with the rules and regulations of the animal committee of Juntendo University School of Medicine.

Induction of diabetes with STZ. At 5 weeks after transplantation, mice were injected intraperitoneally with a low dose of STZ (30 mg/kg [20] or $50 \mathrm{mg} / \mathrm{kg}$ [26] body weight) dissolved in citrate buffer ( $\mathrm{pH} 4.5$ ). Injections were given daily for five consecutive days.

Glucose tolerance test. An intraperitoneal glucose tolerance test (IPGTT) was carried out before STZ injection and at 3 and 5 weeks after STZ injection. After an overnight fast, mice were injected intraperitoneally with glucose $(1.0 \mathrm{~g} / \mathrm{kg}$ body weight). Blood samples were taken from the tail vein at $0,30,60,120$, and $180 \mathrm{~min}$ and the plasma glucose concentration was measured with a Freestyle glucose meter (Kissei Corporation, Nagano, Japan).

Preparation of pancreatic sections and immunohistochemistry. Before and at 1,3, and 5 weeks after STZ injection, mice 


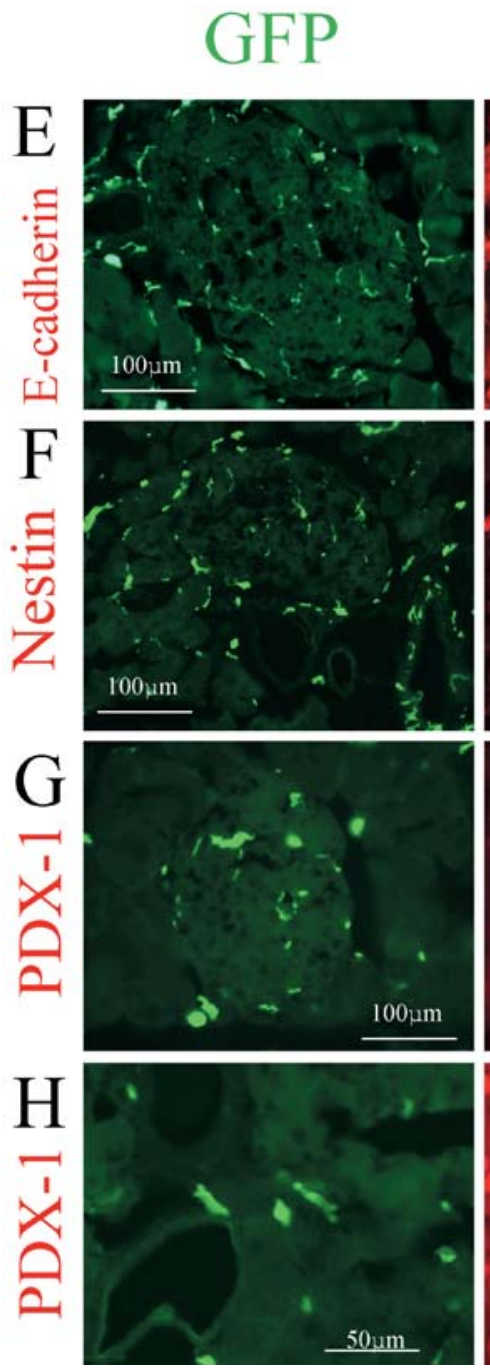

Fig. 2E-H. Legend see page 1368

were thoroughly perfused with PBS followed by $4 \%$ paraformaldehyde under pentobarbital sodium anesthesia. The pancreas was removed and fixed with $4 \%$ paraformaldehyde for 2 days at $4^{\circ} \mathrm{C}$. After then, tissues were placed in $30 \%$ sucrose in PBS for 1 day at $4^{\circ} \mathrm{C}$ and embedded in OCT compound for 2 days at $4^{\circ} \mathrm{C}$. After being frozen on dry ice, the tissues were stored at $-80^{\circ} \mathrm{C}$ until examination. Cryostat sections $(4 \mu \mathrm{m}$ thick) were cut at $-20^{\circ} \mathrm{C}$ and dried on slides overnight at room temperature. The sections were blocked with $10 \%$ goat serum for $30 \mathrm{~min}$ at room temperature, and then incubated with each primary antibody overnight at $4{ }^{\circ} \mathrm{C}$. The primary antibodies were diluted to the following dilutions in $2 \%$ goat serum: $1: 10^{4}$, for rabbit anti-Glucagon, GP anti-human insulin and rabbit anti-Pdx $1 ; 1: 10^{6}$, for mouse anti-Nestin and rabbit anti-vWF; $1: 10^{5}$, for rat anti-mouse CD45; $1: 4000$, for mouse anti-GFP; 1:2500, for mouse anti E-cadherin and 1:200 for rat anti-BrdU. After being washed with PBS three times, the sections were incubated with the appropriate secondary antibodies for $30 \mathrm{~min}$ at room temperature. For detection of Glucagon, Pdx-1, Nestin, vWF, CD45, BrdU, the streptavidin-biotin complex method was used, so biotinylated goat anti-rabbit $\operatorname{IgG}(1: 200)$, biotinylated goat anti-mouse IgG (1:200), or biotinylated goat anti-rat IgG (1:200) was used as the secondary antibody respectively. For the detection
Marker Merge
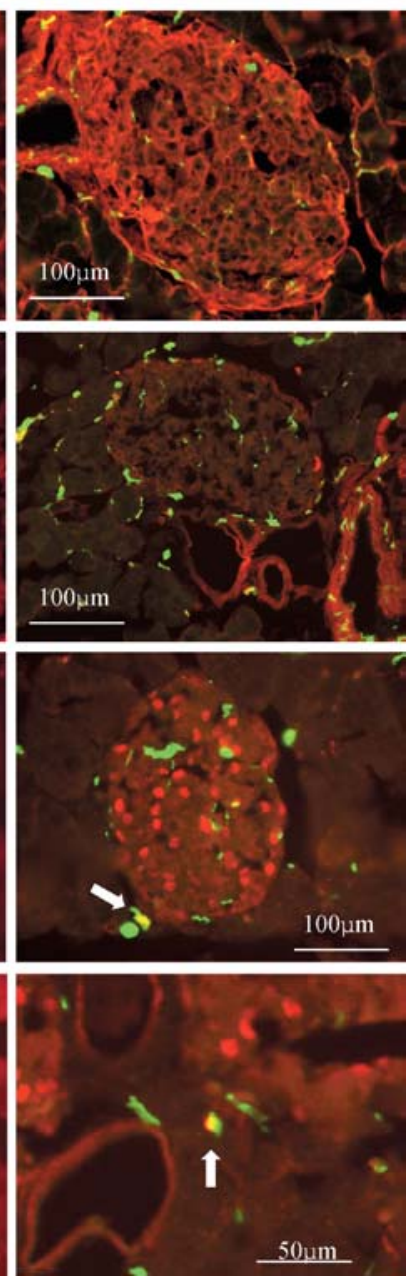

of insulin, goat anti-GP IgG conjugated with Texas-Red $(1: 200)$ was used as the secondary antibody. For the detection of GFP and E-cadherin, goat anti-mouse IgG conjugated with Alexa 568 (1:200) was used as the secondary antibody. Except in the case of staining for insulin, GFP, and E-cadherin after being washed twice with PBS, the sections were incubated with streptavidin (1:200, conjugated Alexa 594, Molecular Probes, Eugene, Ore., USA) for $30 \mathrm{~min}$ at room temperature. Fluorescence from these samples was observed using a Zeiss Axioskop 2 plus microscope (Carl Zeiss, Jena, Germany), and digital images were captured using Axiovision 3.0 software. For the investigation of co-staining with GFP and insulin, we examined 50 to 100 pancreatic sections that contained tissue from the head to the tail and were selected from six pancreata in each of the control and STZ-treated groups. For the detection of other proteins, we examined 3 to $7 \mathrm{sec}-$ tions per protein from each of six mice.

$B r d U$ experiments. To identify the proliferating cells in the pancreas, injection of BrdU was carried out according to the previous protocol $[27,28]$ with some modification. Briefly, mice were injected intraperitoneally with $\mathrm{BrdU}(100 \mathrm{mg} / \mathrm{kg}$ : Sigma-Aldrich, dissolved in $0.007 \mathrm{~N} \mathrm{NaOH}$ in PBS) at 20, 16, 6 , and $2 \mathrm{~h}$ before being killed. Cryostat sections for immunohistochemical analysis of BrdU underwent the following treatment before incubation with the primary antibody: incubation with $2 \mathrm{~N} \mathrm{HCl}$ for $30 \mathrm{~min}$ at $37^{\circ} \mathrm{C}$, incubation with $0.1 \mathrm{~mol} \mathrm{di-}$ sodium tetraborate for $10 \mathrm{~min}$ at room temperature, washing 
with PBS, and rinsing in $50 \mathrm{mmol} / \mathrm{l}$ Tris-bufferred saline (pH 7.6) twice for 5 min each.

After overnight incubation with the primary antibody at $4^{\circ} \mathrm{C}$, the sections were incubated with biotinylated goat anti-rat $\operatorname{IgG}(1: 100)$ as the secondary antibody for $30 \mathrm{~min}$ at room temperature. After washing three times with PBS, the sections were incubated with streptavidin conjugated with horseradish peroxidase (Dako, Carpenteria, Calif., USA) for $30 \mathrm{~min}$ at room temperature. Positive reactions were visualized by incubation with the peroxidase substrate solution containing $3,3^{\prime}$ diaminobenzidine tetrahydrochloride after washing three times with PBS, and the mean number of BrdU-positive cells per islet was calculated from 70 to 100 islets in each group.

Statistics. Differences between groups were analyzed using Student's $t$ test with correction for different variance whenever appropriate. A $p$ value of less than 0.05 was considered statistically significant.

\section{Results}

Characterization of the fate of transplanted bone marrow cells in the pancreas. To investigate the fate of cells derived from bone marrow in the pancreas, we killed the chimeric mice 5 weeks after bone marrow transplantation and stained pancreatic cells with a variety of cell markers. We observed numerous GFP-positive cells in the pancreas and several of the GFP-positive cells were seen in the islets. In addition, the presence of GFP in almost all of the green cells was confirmed by immunostaining using antiGFP antibody (Fig. 1). These results led us to attempt to elucidate the nature of the cells derived from bone marrow within islet. A few cells expressing GFP in islets also expressed the pan-haematopoietic marker CD45, but many other cells did not (Fig. 2A). We could also find a few GFP-positive cells expressing the endothelial cell-marker vWF (Fig. 2B). These results suggested that cells derived from the transplanted bone marrow had undergone differentiation into haematopietic cells or endothelial cells. However we found some GFP-positive cells that did not express either of markers.

To explore the possibility of transdifferentiation from bone marrow-derived cells into pancreatic endocrine cells, we investigated the expression of insulin and glucagon in GFP-positive cells. We investigated 50 to 100 pancreatic sections from each of six mice which were stained with insulin antibodies. We carefully selected sections from each pancreas that should contain tissue from the pancreatic head to the pancreatic tail. However, we could not find any insulin or glucagon expression in GFP-positive cells (Fig. 2C,D). Furthermore, we could not identify any GFP-positive cells expressing E-cadherin, which is a marker of endodermal epithelial cells (Fig. 2E). This suggested that almost all of the GFP-positive cells in the islets might be mesenchymal cells.

Previous studies have reported transdifferentiation events between different types of somatic stem cells.
A

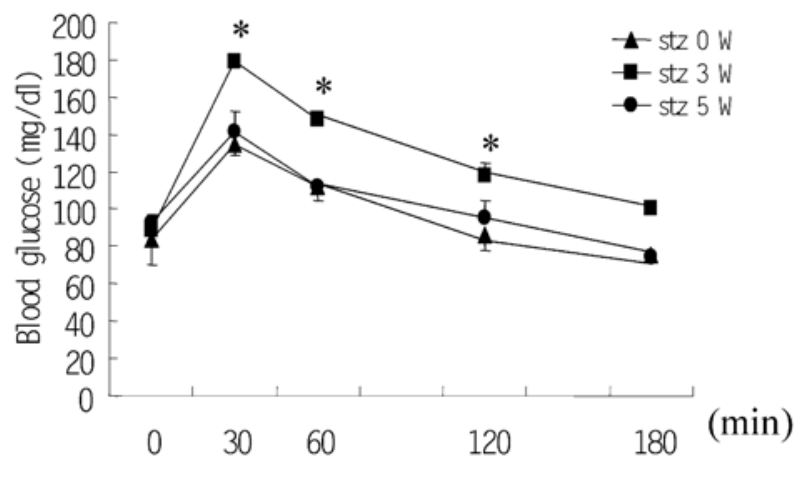

\section{B BrdU incorporation}

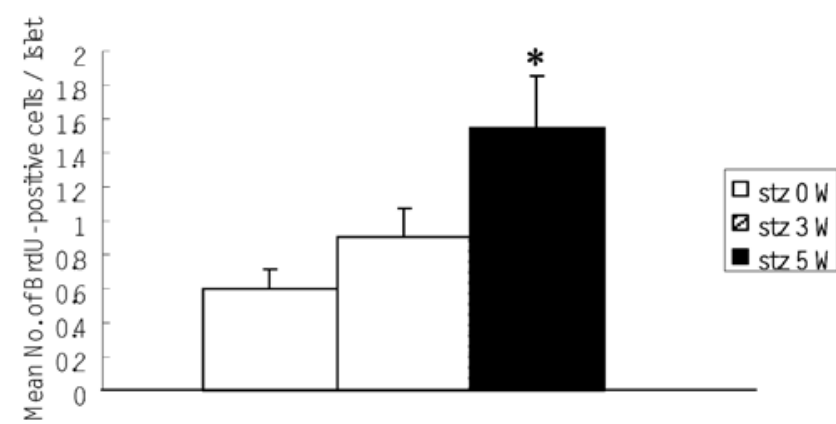

Fig. 3A, B. Changes of glucose tolerance and islet cell replication after $30 \mathrm{mg} / \mathrm{kg}$ of STZ for 5 days. (A) Results of the intraperitoneal glucose $(1.0 \mathrm{~g} / \mathrm{kg})$ tolerance test in GFP chimeric mice $(\mathrm{C} 57 \mathrm{Bl} / 6)$ before and 3 and 5 weeks after treatment with STZ at $30 \mathrm{mg} / \mathrm{kg}$ intraperitoneally for 5 days (each group: $n=5$, ${ }^{*} p<0.05$ : stz $0 \mathrm{~W}$ vs stz $3 \mathrm{~W}$ ). (B) The mean number of BrdUincorporating cells per islet after multiple injections of $\mathrm{BrdU}$ was calculated before and 3 and 5 weeks after treatment with STZ (each group: $n=5,{ }^{*} p<0.05$ : stz $0 \mathrm{~W}$ vs stz $5 \mathrm{~W}$ ). All data are expressed as the means \pm SEM

In the pancreas, no obvious stem cells have been identified so far. If the stem cells from transplanted bone marrow underwent differentiation into islet stem cells, it might be possible to observe GFP-positive cells expressing nestin within the islets. However, we could not find any GFP-positive cells in islets that also expressed nestin (Fig. 2F).

$\mathrm{Pdx} 1$ is a transcription factor involved in pancreatic development, its expression is mainly observed in pancreatic beta cells and occasionally in exocrine cells and duct cells in the adult pancreas. We could not find any GFP-positive cells expressing Pdx 1 in the islets in agreement with the lack of GFP-positive cells expressing insulin (Fig. 2G). In contrast, there were a few GFP-positive cells expressing Pdx1 outside the islets (Fig. 2G,H). These findings suggested that stem cells derived from transplanted bone marrow could differentiate into pancreatic cells. 


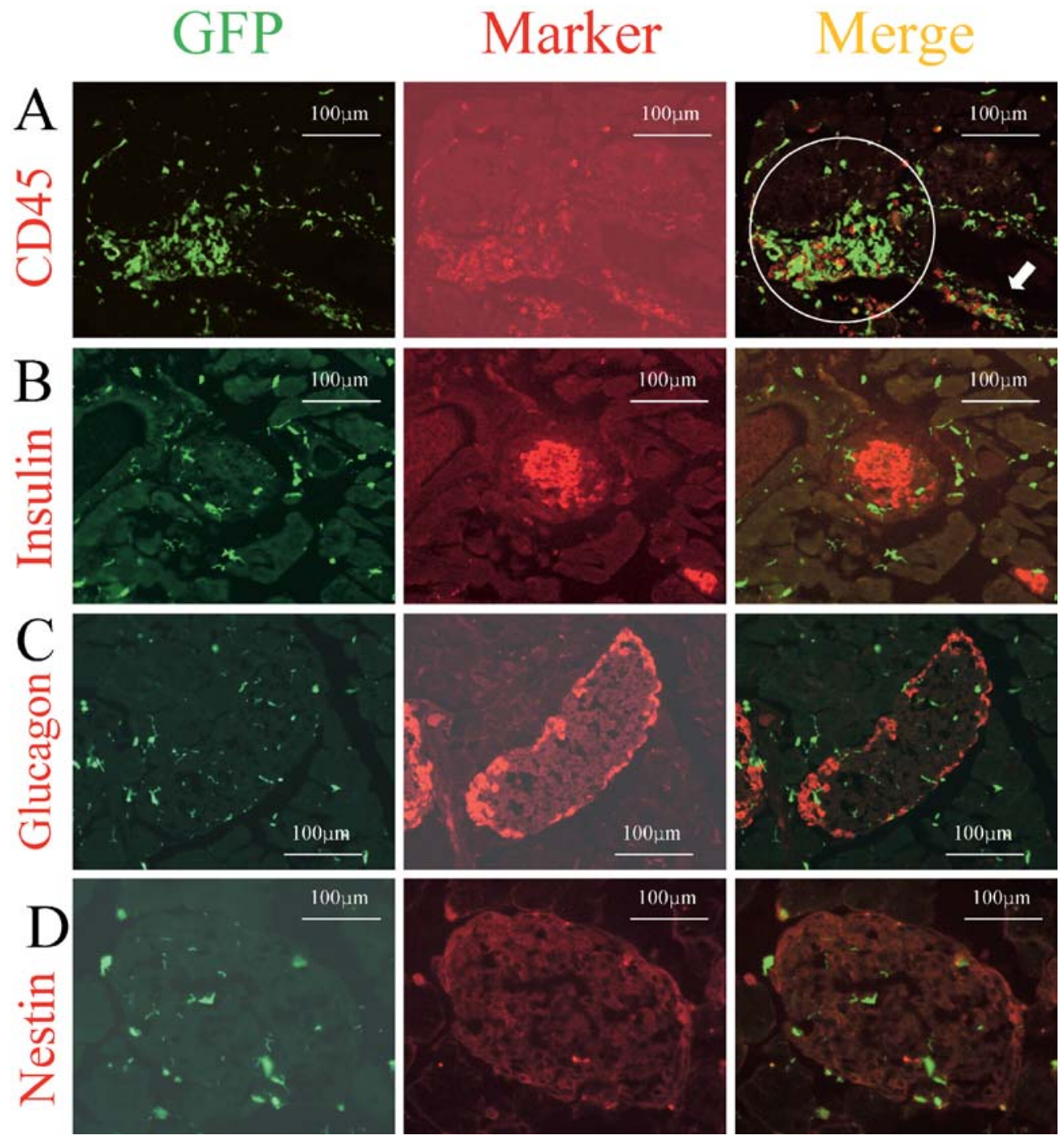

Fig. 4A-D. Distribution of GFP-positive cells and several markers after STZ treatment at $30 \mathrm{mg} / \mathrm{kg}$. Immunohistochemical analysis was carried out on cryostat sections $(4 \mu \mathrm{m})$ from the pancreas of mice treated with multiple doses of STZ at $30 \mathrm{mg} / \mathrm{kg}$. Left, middle, and right panels show GFP as green, each marker as red, and the merged image, respectively. These sections were immunostained with anti-CD45 antibody (A), anti-insulin antibody (B), anti-glucagon antibody (C), and antinestin antibody (D)

The lineage of bone marrow-derived cells after destruction of pancreatic beta cells. The presence of a few GFP-positive cells expressing Pdx1 suggested that bone marrow-derived cells could differentiate into pancreatic cells. However, the reason for not finding any GFP-positive cells expressing insulin might have been because differentiation of bone marrow-derived stem cells into beta-cells is too rare to detect in normal mice. Therefore, we treated mice with multiple low-dose injections of STZ to destroy beta cells, and then observed the regeneration and replication of these cells in the islets. Firstly, we gen- erated chimeric mice and 5 weeks after bone marrow transplantation, we injected $30 \mathrm{mg} / \mathrm{kg}$ of STZ daily for 5 days. One day after the last injection, damaged islets were identified by insulin staining of the pancreas (data not shown). Reflecting the destruction of some islets, the glucose tolerance of these mice had deteriorated 3 weeks after STZ treatment. However, glucose tolerance almost recovered to normal by 5 weeks (Fig. 3A). In addition, we counted BrdU-positive cells in the islets of mice before and 3 and 5 weeks after STZ treatment $(30 \mathrm{mg} / \mathrm{kg})$. A gradual increase in the number of BrdU-positive cells was seen in the islets (Fig. 3B), also some of the BrdU-positive cells expressed insulin, while others did not, suggesting that cell replication and/or regeneration might be occurring. At 5 weeks after STZ treatment, the accumulation of GFP-and CD45-positive cells in the periductal area of the pancreas may reflect the healing process after inflammation (Fig. 4A). Even under these conditions, we could not find any GFPpositive cells expressing insulin, glucagon, or nestin in the islets and periductal areas(Fig. 4B,C,D). Further, we found no obvious change in the number of 
A stz $50 \mathrm{~m} / \mathrm{kg}$

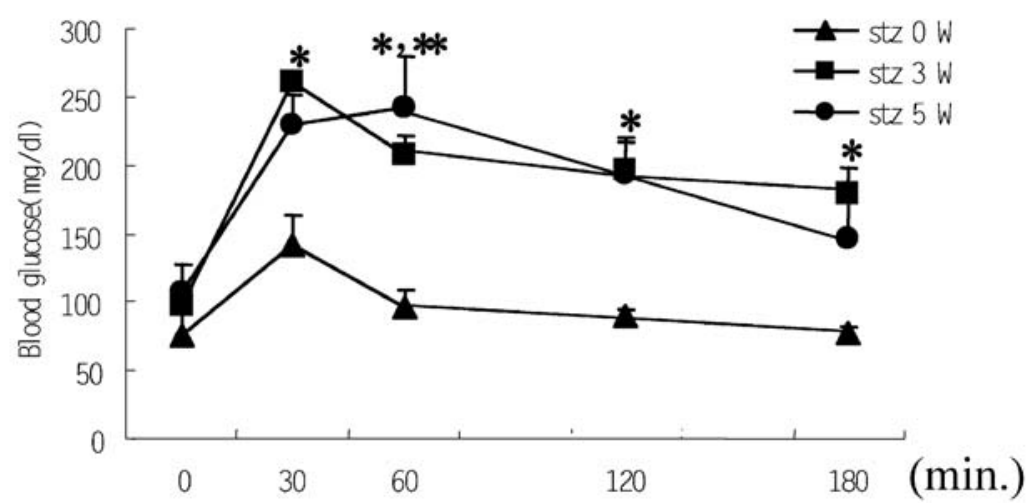

B

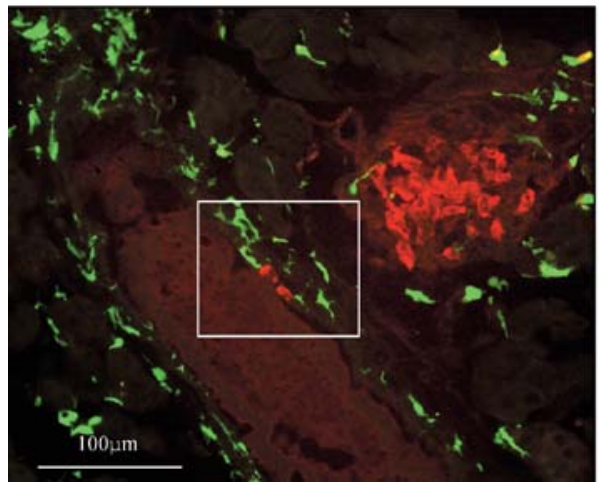

Fig. 5A-C. Distribution of GFP-positive cells after STZ treatment at $50 \mathrm{mg} / \mathrm{kg}$. (A) Results of the intraperitoneal glucose $(1.0 \mathrm{~g} / \mathrm{kg})$ tolerance test in GFP chimeric mice $(\mathrm{C} 57 \mathrm{Bl} / 6)$ before and 3 and 5 weeks after treatment with STZ $(50 \mathrm{mg} / \mathrm{kg}$ injected intraperitoneally for 5 days). Data are expressed as the means \pm SEM (each group: $n=5, * p<0.05$ : stz $0 \mathrm{~W}$ vs stz $3 \mathrm{~W}$; ${ }^{* *} p<0.05$ : stz $0 \mathrm{~W}$ vs stz $5 \mathrm{~W}$ ). (B, C) Immunohistochemical analysis of cryostat sections $(4 \mu \mathrm{m})$ from the pancreas of mice treated with multiple doses of STZ $(50 \mathrm{mg} / \mathrm{kg})$. The merged images of GFP and Insulin-immunostaining are shown. A white arrow indicates periductal cells expressing insulin

GFP-positive cells expressing Pdx1 outside the islets (data not shown).

Next, we increased the dose of STZ to $50 \mathrm{mg} / \mathrm{kg}$ for 5 days. After this treatment, we found the deterioration of glucose tolerance from 3 to 5 weeks (Fig. 5A). At 5 weeks after treatment, there was a decrease of insulin-positive cells in the islets (Fig. 5B) and a some insulin staining surrounding ducts, suggesting the occurrence of regeneration events from periductal cells. However, we could not find any GFPpositive cells expressing insulin in the islets or around the ducts (Fig. 5B,C).

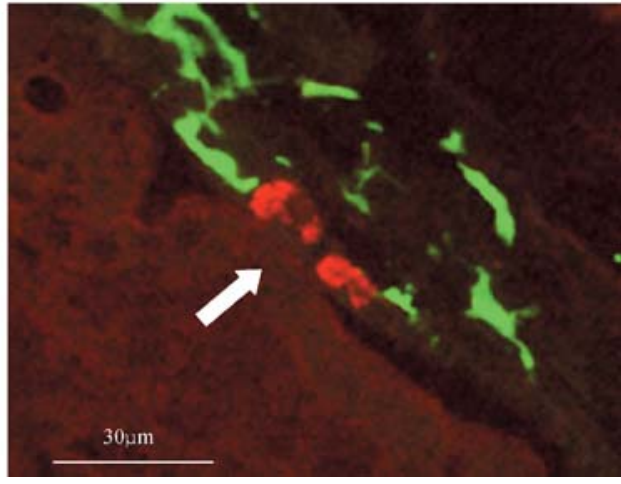

Discussion

In this study, we focused on the fate of transplanted bone marrow cells in the pancreas. At 5 weeks after bone marrow transplantation, we could not find any cells derived from the bone marrow expressing insulin despite intensive observation.

Several groups have already generated chimeric mice or carried out transplantation using isolated haematopoietic stem cells or mescenchymal stem cells and have tried to identify the cells derived from bone marrow in various tissues and found that bone marrow-derived stem cells differentiated into various tissue specific cells $[12,13]$. During the preparation of this manuscript, another study showed that bone marrow-derived cells differentiated into insulin expressing cells [33]. This report showed that bone marrow cells could differentiate into beta cells. Through a genetic approach, the authors ruled out cell fusion as the mechanism for EGFP-positive cells with islet-like characteristics. If this is the case, why did we not find transdifferentiation into pancreatic beta cells? A recent report contradicted an earlier study [34] and suggested that neural stem cells rarely transdifferentiated 
into blood cells [35]. Another study reported that a single haematopoietic stem cell robustly reconstituted peripheral blood leukocytes, but did not contribute appreciably to non-haematopoietic tissues, including the brain, kidney, gut, liver, and muscle. Furthermore, they used parabolic mice to enable the massive transfer of haematopoietic stem cells, but few transdifferentiational events were observed [36]. We cannot point out the solid reason for these conflicts. Only the difference of experimental condition could explain the conflicting results. Thus, in this paper, we would like to emphasize that under the experimental condition described here, we could not show the contribution of bone marrow-derived cells to differentiate into islet cells.

Previous studies have shown that tissue injury enhances the recruitment of haematopietic stem cells, mescenchymal stem cells or their progeny to non-haematopoietic fate $[11,14,15,16]$. Intravenous injection of adult bone marrow cells in FAH(-/-) mice, an animal model of tyrosinemia type I, rescued these animals and restored the biochemical functions of the liver. In these mice, surprisingly, as few as 50 highly purified haematopoietic stem cells could be induced to generate large colonies of functional hepatocytes [11]. In our study, using mice treated with low-dose STZ as a model of selective pancreatic beta-cell injury, we explored the transformation of cells derived from the bone marrow to insulin-positive cells. In the pancreas, we observed an increase of cell proliferation in islet cells and a few insulin-positive cells surrounding the pancreatic ducts, but we could not find any insulin-expressing cells derived from bone marrow cells.

We used low-dose STZ as a tissue injury model. However, several other models of pancreatic injury, such as partial pancreatectomy [37] or cellophane wrapping [38], have been established. Each model might involve a different mechanism of regeneration of the pancreas, so, we cannot deny the possibility that transdifferentiation into pancreatic beta cells might be observed in a different model of tissue injury.

In conclusion, with regard to beta-cell replacement therapy for diabetes, our data suggests that bone marrow-derived stem cells cannot differentiate into beta cells automatically. However, our data does not deny the feasibility of bone marrow-derived cells as a host cells for beta-cell replacement therapy. Recently several lines of evidence have suggested that the expression of Pdx 1 into various cells can provoke differentiation into cells similar to pancreatic beta-cells $[39,40$, $41,42]$, so introducing a beta-cell differentiation factor like Pdx1 into bone marrow-derived stem cells seems to be worth investigating.

Acknowledgements. We would like to thank to M. Okabe (Osaka University) for GFP transgenic mice, S. Hockfield (Yale University) for mouse anti-nestin antibody, and also Mrs. N. Daimaru for excellent technical assistance. This study was supported in part by grants from the Juvenile Diabetes Re- search Foundation International (to H.W.), the Ministry of Education, Culture, Sports, and Technology of Japan (to H.W.), Takeda Medical Research Foundation (to H.W.) and a High Technology Research Center Grant from the Ministry of Education, Culture, Sports, Science and Technology of Japan (to H.M.).

\section{References}

1. Fuchs E, Segre JA (2000) Stem cells: a new lease on life. Cell 100:143-155

2. Ramiya VK, Maraist M, Arfors KE, Schatz DA, Peck AB, Cornelius JG (2000) Reversal of insulin-dependent diabetes using islets generated in vitro from pancreatic stem cells. Nat Med 6:278-282

3. Zulewski H, Abraham EJ, Gerlach MJ et al. (2001) Multipotential nestin-positive stem cells isolated from adult pancreatic islets differentiate ex vivo into pancreatic endocrine, exocrine, and hepatic phenotypes. Diabetes 50:521533

4. Guz Y, Nasir I, Teitelman G (2001) Regeneration of pancreatic beta cells from intra-islet precursor cells in an experimental model of diabetes. Endocrinology 142:49564968

5. Bonner-Weir S, Taneja M, Weir GC et al. (2000) In vitro cultivation of human islets from expanded ductal tissue. Proc Natl Acad Sci USA 97:7999-8004

6. Jackson KA, Majka SM, Wulf GG, Goodell MA (2002) Stem cells: a minireview. J Cell Biochem [Suppl] 38:1-6

7. Orlic D, Kajstura J, Chimenti S et al. (2001) Bone marrow cells regenerate infarcted myocardium. Nature 410:701-705

8. Hess DC, Hill WD, Martin-Studdard A, Carroll J, Brailer J, Carothers J (2002) Bone marrow as a source of endothelial cells and NeuN-expressing cells after stroke. Stroke 33: 1362-1368

9. Otani A, Kinder K, Ewalt K, Otero FJ, Schimmel P, Friedlander M (2002) Bone marrow-derived stem cells target retinal astrocytes and can promote or inhibit retinal angiogenesis. Nat Med 8:1004-1010

10. Eglitis MA, Mezey E (1997) Hematopoietic cells differentiate into both microglia and macroglia in the brains of adult mice. Proc Natl Acad Sci USA 94:4080-4085

11. Lagasse E, Connors H, Al-Dhalimy M et al. (2000) Purified hematopoietic stem cells can differentiate into hepatocytes in vivo. Nat Med 6:1229-1234

12. Krause DS, Theise ND, Collector MI et al. (2001) Multiorgan, multi-lineage engraftment by a single bone marrowderived stem cell. Cell 105:369-377

13. Jiang Y, Jahagirdar BN, Reinhardt RL et al. (2002) Pluripotency of mesenchymal stem cells derived from adult marrow. Nature 418:41-49

14. Theise ND, Henegariu O, Grove J et al. (2002) Radiation pneumonitis in mice: a severe injury model for pneumocyte engraftment from bone marrow. Exp Hematol 30:1333-1338

15. Ito T, Suzuki A, Okabe M, Imai E, Hori M (2001) Application of bone marrow-derived stem cells in experimental nephrology. Exp Nephrol 9:444-450

16. Tanaka R, Komine-Kobayashi M, Mochizuki H et al. (2003) Migration of enhanced green fluorescent protein expressing bone marrow-derived microglia/macrophage into the mouse brain following permanent focal ischemia. Neuroscience 117:531-539

17. Fernandes A, King LC, Guz Y, Stein R, Wright CV, Teitelman G (1997) Differentiation of new insulin-producing cells is induced by injury in adult pancreatic islets. Endocrinology 138:1750-1762 
18. Wang Z, Dohle C, Friemann J, Green BS, Gleichmann H (1993) Prevention of high- and low-dose STZ-induced diabetes with D-glucose and 5-thio-D-glucose. Diabetes 42:420-428

19. Burkart V, Wang ZQ, Radons J et al. (1999) Mice lacking the poly(ADP-ribose) polymerase gene are resistant to pancreatic beta-cell destruction and diabetes development induced by streptozocin. Nat Med 5:314-319

20. Kim BM, Han YM, Shin YJ, Min BH, Park IS (2001) Clusterin expression during regeneration of pancreatic islet cells in streptozotocin-induced diabetic rats. Diabetologia 44:2192-2202

21. Nakano K, Migita M, Mochizuki H, Shimada T (2001) Differentiation of transplanted bone marrow cells in the adult mouse brain. Transplantation 71:1735-1740

22. Hayakawa J, Migita M, Urabe T, Shimada T, Fukunaga Y (2003) Generation of a chimeric mouse reconstituted with GFP (+) bone marrow cells. Int J Hematol (in press)

23. Furuya T, Tanaka R, Urabe T et al. (2003) Establishment of modified chimeric mice using GFP bone marrow as a model for neurological disorders. Neuroreport 13:1-3

24. Watada H, Kajimoto Y, Umayahara Y et al. (1996) The human glucokinase gene beta-cell-type promoter: an essential role of insulin promoter factor $1 / \mathrm{PDX}-1$ in its activation in HIT-T15 cells. Diabetes 45:1478-1488

25. Okabe M, Ikawa M, Kominami K, Nakanishi T, Nishimune Y (1997) 'Green mice' as a source of ubiquitous green cells. FEBS Lett 407:313-319

26. George M, Ayuso E, Casellas A, Costa C, Devedjian JC, Bosch F (2002) Beta cell expression of IGF-I leads to recovery from type 1 diabetes. J Clin Invest 109:11531163

27. Suzuki A, Zheng Yw YW, Kaneko S et al. (2002) Clonal identification and characterization of self-renewing pluripotent stem cells in the developing liver. J Cell Biol 156: $173-184$

28. Jorns A, Tiedge M, Lenzen S (2002) Thyroxine induces pancreatic beta cell apoptosis in rats. Diabetologia 45: 851-855

29. Selander L, Edlund H (2002) Nestin is expressed in mesenchymal and not epithelial cells of the developing mouse pancreas. Mech Dev 113:189-192

30. Offield MF, Jetton TL, Labosky PA et al. (1996) PDX-1 is required for pancreatic outgrowth and differentiation of the rostral duodenum. Development 122:983-995
31. Ahlgren U, Jonsson J, Edlund H (1996) The morphogenesis of the pancreatic mesenchyme is uncoupled from that of the pancreatic epithelium in IPF1/PDX1-deficient mice. Development 122:1409-1416

32. Guz Y, Montminy MR, Stein R et al. (1995) Expression of murine STF-1, a putative insulin gene transcription factor, in beta cells of pancreas, duodenal epithelium and pancreatic exocrine and endocrine progenitors during ontogeny. Development

33. Ianus A, Holz GG, Theise ND, Hussain MA (2003) In vivo derivation of glucose-competent pancreatic endocrine cells from bone marrow without evidence of cell fusion. J Clin Invest 111:843-850

34. Bjornson CR, Rietze RL, Reynolds BA, Magli MC, Vescovi AL (1999) Turning brain into blood: a hematopoietic fate adopted by adult neural stem cells in vivo. Science 283:534-537

35. Morshead CM, Benveniste P, Iscove NN, van der Kooy D (2002) Hematopoietic competence is a rare property of neural stem cells that may depend on genetic and epigenetic alterations. Nat Med 8:268-273

36. Wagers AJ, Sherwood RI, Christensen JL, Weissman IL (2002) Little evidence for developmental plasticity of adult hematopoietic stem cells. Science 297:2256-2259

37. Bonner-Weir S, Baxter LA, Schuppin GT, Smith FE (1993) A second pathway for regeneration of adult exocrine and endocrine pancreas. A possible recapitulation of embryonic development. Diabetes 42:1715-1720

38. Rosenberg L, Brown RA, Duguid WP (1983) A new approach to the induction of duct epithelial hyperplasia and nesidioblastosis by cellophane wrapping of the hamster pancreas. J Surg Res 35:63-72

39. Yoshida S, Kajimoto Y, Yasuda T et al. (2002) PDX-1 induces differentiation of intestinal epithelioid IEC-6 into insulin-producing cells. Diabetes 51:2505-2513

40. Ferber S, Halkin A, Cohen H et al. (2000) Pancreatic and duodenal homeobox gene 1 induces expression of insulin genes in liver and ameliorates streptozotocin-induced hyperglycemia. Nat Med 6:568-572

41. Watada H, Kajimoto Y, Miyagawa J et al. (1996) PDX-1 induces insulin and glucokinase gene expressions in alphaTC 1 clone 6 cells in the presence of betacellulin. Diabetes 45:1826-1831

42. Horb ME, Shen CN, Tosh D, Slack JM (2003) Experimental conversion of liver to pancreas. Curr Biol 13:105-115 